UDK $630 * 232.31$

Original scientific paper

\title{
DIFFERENT METHODS FOR BEECH SEED QUALITY TESTING
}

\author{
Ivona KERKEZl, Slavko PAVLOVIĆ', Aleksandar LUČIĆ', \\ Jovana DEVETAKOVIĆ ${ }^{l}$, Mirjana ŠIJAČIĆ-NIKOLIĆ ${ }^{l}$, Vladan POPOVIĆ
}

\begin{abstract}
This paper presents three different methods for beech seed quality testing. The aim of this study is to determine the correlation between the electrical conductivity test, tetrazolium test and hydrogen peroxide treatment. The seed was collected in 12 different seed stands in Serbia that are commonly used for nursery production. The seed sample used for testing was randomly taken from the total amount of the collected seed. The analysis of the obtained results included the calculation of the Pearson correlation coefficient in the statistical software package "Statistica 7". The correlation was determined between the recorded results of the seed weight and the electrical conductivity; the seed weight and the tetrazolium test; the seed weight and the hydrogen peroxide treatment; the electrical conductivity and the tetrazolium test; the electrical conductivity and the hydrogen peroxide treatment; the tetrazolium test and the hydrogen peroxide treatment. Based on the conducted researches it can be concluded that the standardization of the electrical conductivity test using the tetrazolium test and hydrogen peroxide treatment could contribute to a more quality and more comprehensive determination of the beech seed quality for commercial purposes.
\end{abstract}

Key words: Seed quality, seed stands, beech.

\section{RAZLIČITE METODE ZA ISPITIVANJE KVALITETA SEMENA BUKVE}

\begin{abstract}
Abstrakt: $U$ radu su prikazane tri različite metode za testiranje kvaliteta semena bukve. Cilj ovog istraživanja je utvrđivanje korelacijskih odnosa između testa električne provodljivosti, tetrazolijum testa $i$ tretmana semena vodonik peroksidom. Seme je sakupjeno iz 12 različitih semenskih sastojina na području Srbije, koje se uobičajeno koriste za sakupljanje semena za rasadničku proizvodnju. Testirani uzorak je nasumično
\end{abstract}

\footnotetext{
${ }^{1}$ University of Belgrade - Faculty of Forestry, Belgrade, Serbia

${ }^{2}$ Institute of Forestry, Belgrade, Serbia
} 
odabran iz ukupne količine sakupljenog semena. Analiza dobijenih rezultata obuhvatila je izračunavanje Pirsonovog koeficijenta korelacije u statističkom programu "Statistica 7". Utvrđena je korelacija između zabeleženih rezultata mase semena i električne provodljivosti, tetrazolium testa i tretmana vodonik peroksidom; električne provodljivosti $i$ tetrazolijum testa $i$ vodonik peroksid tretmana, kao i između tetrazolijum testa $i$ vodonik peroksid tretmana. Na osnovu sprovedenih istraživanja može se zaključiti da standardizacijom testa električne provodljivosti uz primenu tetrazolijum testa $i$ vodonik peroksid tretmana doprinelo bi se kvalitetnijem i bržem utvrđivanju kvaliteta semena bukve u komercijalne svrhe.

Ključne reči: kvalitet semena, semenske sastojine, bukva.

\section{INTRODUCTION}

As it is well known, the seed quality is very important in the nursery production from the economic point of view and optimizing storage conditions is one of the major tasks for producers. The seed of the European beech possess a deep embryo dormancy resulting in an enormous seed loss and poor seedling production in nurseries (Muller \& Bonnet-Masimbert, 1982). This embryo dormancy inhibits germination of viable, mature embryos even when there are conditions suitable for germination. The dormancy is controlled by environmental, physiological and genetic factors (Milošević et al. 1996). The most common way of storage of beech seeds is in a fridge (at the temperature of about $5^{\circ} \mathrm{C}$ ) in the paper/plastic bags for about six mounts. Sometimes the storage can last longer, which may or may not necessarily reduce the quality of the seeds (Suszka, 1974; Suszka and Zieta 1977; Muller \& Bonnet-Masimbert 1982; Muller, 1993; Gosling, 1991; Soltani, 2003). The seed aging processes are controlled by the temperature and the moisture conditions, and may be associated with various chemical reactions and metabolic alterations (Vertucci and Ross, 1990; Walters, 1998). The accumulation of reactive oxygen species (ROS) is often indicated as the prime cause of the seed deterioration, as it initiates reactions with polyunsaturated fatty acids, leading to lipid peroxidation and destruction of cellular membranes (Poter et al., 1947; Senaratna et al., 1988; Pukacka, 1991; Copeland and McDonald, 2001; Pukacka and Ratajzcak, 2004; Ivetic, Milovanovic 2005), but this membrane structure can be repaired after soaking seeds in the water (Ivetic and Milovanovic 2005).

The seed quality is mostly assessed by the seed germination rate but carrying out this method requires a long period of time, namely, in extreme case up to 24 weeks (Edwards and Wang, 1995). Also some viable seeds won't germinate due to dormancy which can be removed. Therefore, an effort was made to find a faster, nondestructive and easily preformed method for the seed quality testing. One of the solutions is to assess the seed viability, which is an indicator of the seed ability to germinate and produce normal seedlings under suitable conditions (Copeland and McDonald, 2001; Ivetić, 2013).

Three different methods for the seed quality determination were presented in this paper. The aim of this research is to determine a correlation between electrical conductivity test, tetrazolium test and hydrogen peroxide treatment. 


\section{MATERIALS AND METHODS}

The seeds were collected from 12 beech seed stands in Serbia which are usually used for the nursery production (Table 1). The seeds were stored in a fridge (at the temperature of about $5^{\circ} \mathrm{C}$ ) in the paper bags for two years. The absolute seed weight was measured for each population, with a hundredth of gram accuracy, on a sample of 100 seeds in four repetitions. The seed moisture content was determined according to the SRPS and ISTA rules by drying the seeds in the oven at $130^{\circ} \mathrm{C}$ for an hour. The seed testing with the electrical conductivity test, tetrazolium test and hydrogen peroxide treatment was performed on seeds randomly selected from the total amount of collected seeds.

The electrical conductivity test was first performed using a method described by Ivetić (2013). It was performed on 10 seeds in 3 repetitions, in the total of 30 seeds per population. The seeds were soaked in $20 \mathrm{ml}$ of deionized water whose electrical conductivity was previously measured. The closed plastic containers were left for 24 hours at the temperature of $20-25^{\circ} \mathrm{C}$. After that period the electrical conductivity was measured by Mettler Toledo FiveEasy Plus ${ }^{\mathrm{TM}} \mathrm{pH}$ benchtop meter with a measuring range $-1999-1999 \mathrm{mV}$ and an accuracy $\pm 1 \mathrm{mV}$. The specific electrical conductivity per gram of dry seeds was calculated according to the formula 1 where the SEC is the specific electrical conductivity $[\mu \mathrm{S} / \mathrm{cm} / \mathrm{g} / \mathrm{mL}]$ and SWDC - seed weight in dry condition [g].

$$
S E C=\frac{\text { measured conductivity }[\mu \mathrm{S}]}{\text { SWDC }[\mathrm{g}] \mathrm{x} \text { quantity of water }[\mathrm{mL}]}[\mu \mathrm{S} / \mathrm{cm} / \mathrm{g} / \mathrm{mL}]
$$

Table 1. General characteristics of studied beech seed stands

\begin{tabular}{|l|c|c|c|}
\hline \multicolumn{1}{|c|}{ Seed stands } & Altitude & Region of provenance & $\begin{array}{c}\text { The registration } \\
\text { number }\end{array}$ \\
\hline MU "Deli Jovan" & $567-720 \mathrm{~m}$ & $34-$ northeastern Serbia & RS-1-1-fsy-34-796 \\
\hline MU "Južni Kučaj" & $890-960 \mathrm{~m}$ & $34-$ northeastern Serbia & RS-2-2-fsy-34-378 \\
\hline MU "Kamenička reka" & $400-490 \mathrm{~m}$ & 34- northeastern Serbia & RS-1-1-fsy-34-794 \\
\hline MU "Bukovik" & $740-910 \mathrm{~m}$ & $34-$ northeastern Serbia & RS-1-1-fsy-34-791 \\
\hline MU "Venac-Blagaja" & $790-940 \mathrm{~m}$ & $32-$ western Serbia & RS-1-1-fsy-32-802 \\
\hline MU "Srndaljska reka" & $780-1180 \mathrm{~m}$ & $33-$ south Serbia & RS-1-1-fsy-33-679 \\
\hline MU "Miroč" & $289-500 \mathrm{~m}$ & $34-$ northeastern Serbia & RS-1-1-fsy-34-795 \\
\hline MU "Dubašnica I" & $390-460 \mathrm{~m}$ & 34- northeastern Serbia & RS-1-1-fsy-34-793 \\
\hline MU "Medveđa" & $720-950 \mathrm{~m}$ & 35- southeastern Serbia & RS-1-2-fsy-35-816 \\
\hline MU "Kukavica" & $920-1210 \mathrm{~m}$ & 35- southeastern Serbia & RS-1-2-fsy-35-817 \\
\hline MU "Dubašnica" & $860-890 \mathrm{~m}$ & 34- northeastern Serbia & RS-2-2-fsy-34-373 \\
\hline MU "Mali Jastrebac" & $790 \mathrm{~m}$ & 33- south Serbia & RS-2-2-fsy-33-633 \\
\hline
\end{tabular}

The tetrazolium test was performed on the same seed samples using a method recommended in Draper et al., 1985; Ivetić, 2013; Verma and Majee, 2013. The seeds were soaked in the plastic containers filled with $25 \mathrm{ml}$ of deionized water for 24 hours. After that period, the seed coat was removed. The staining was done at the temperature of $20-25^{\circ} \mathrm{C}$ in $25 \mathrm{ml}$ of $1 \%$ solution of $2.3-5$ triphyltetrazolium chloride solution and left for 24 hours in a dark. The seeds were taken from the plastic containers with tweezers and cut longitudinally trough cotyledons to expose the inner side of the cotyledons. In dependence of the seed staining, the seeds were rated from 1 (totally dead seeds) to 5 (vital seeds) (Picture 
1). As Verma and Majee (2013) states, among stained seeds, the seeds with bright red staining are completely viable and they give normal seedlings, while partially stained seeds may produce either normal or abnormal seedlings. Pink or greyish stained seeds indicate the presence of a dead tissue in the seed, while completely unstained seeds are non-viable. The average seed assessment category was used as an input for the correlation analysis for each population.

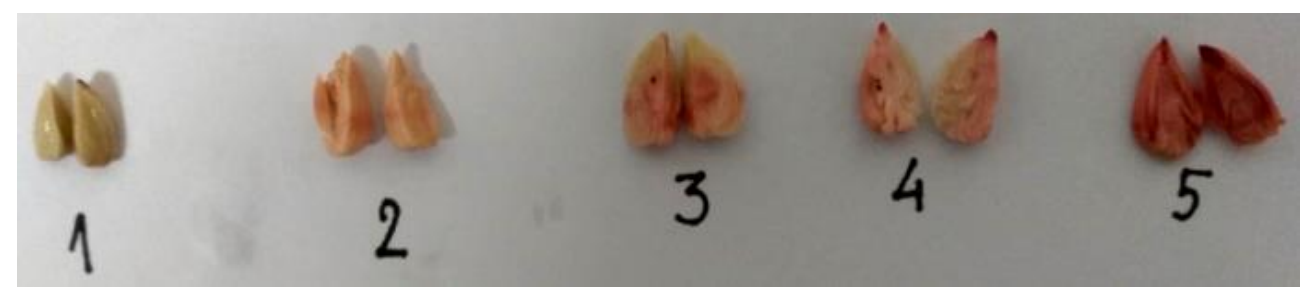

Picture 1. Seed assessment categories

The sample for the hydrogen peroxide treatment was the same as for the previous tests (10 seeds in 3 repetitions, the total of 30 seeds per population). The test was performed in two repetitions, as described by Ivetić $(2002,2013)$. The samples were soaked in $100 \mathrm{ml}$ of $1 \%$ hydrogen peroxide solution at the temperature of $20-25^{\circ} \mathrm{C}$. Next day the seed coat was cut in radicular direction, and again soaked in $150 \mathrm{ml}$ of $1 \%$ hydrogen peroxide solution for three days. After third day the solution was refreshed. The germinated seeds were counted after three and seven days (Picture 2). The percentage of the germinated seeds was determined for each population.

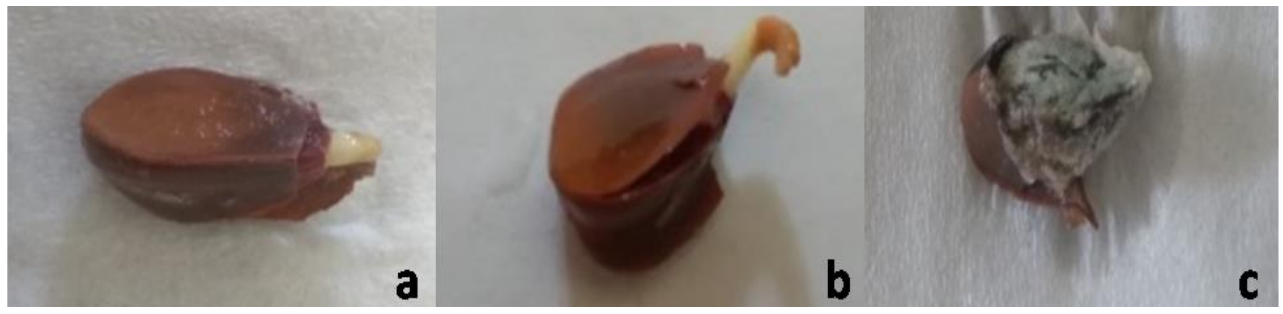

Picture 2. Germinated seeds: third day (a); seventh day (b); mildew seed (c)

\section{RESULTS AND DISCUSSION}

The analysis of the obtained results (Table 2) included the calculation of the Pearson correlation coefficient in the statistical software package "Statistica 7". The correlation (Graph 1) was determined between the recorded results of the seed weight and the electrical conductivity (A); the seed weight and the tetrazolium test (B); the seed weight and the hydrogen peroxide treatment (C); the electrical conductivity and the tetrazolium test (D); the electrical conductivity and the hydrogen peroxide treatment $(\mathrm{E})$; the tetrazolium test and the hydrogen peroxide treatment $(\mathrm{F})$.

It is well known that heavy seeds germinate faster and have higher germination ability, so the positive correlation between the seed weight and the 
germination ability is present in almost all seeds and it is associated with high content of nutrients that causes stronger and faster emergence of the radicle (Soltani, 2003). In the beech seed, this correlation is explained by the increased genetic diversity of this species (Comps et al., 1998). According to the shown results (Graph 1), the seed weight is in the positive correlation with the results of the tetrazolium test $(r=0.51)$ and the hydrogen peroxide treatment $(r=0.27)$, and in the negative correlation with the results of the electrical conductivity test $(\mathrm{r}=$ $0.15)$. The negative correlation was also obtained in the ratio of the results of the electrical conductivity and the tetrazolium test $(\mathrm{r}=-0.46)$, as well as in the hydrogen peroxide treatment $(r=-0.26)$. A small value of the correlation coefficient can also be the consequence of a small number of variables.

Table 2. Mean values per population

\begin{tabular}{|l|l|c|c|c|c|c|}
\hline Label & Population & $\begin{array}{c}\text { WG } \\
{[\mathrm{g}]}\end{array}$ & $\begin{array}{c}\text { HU } \\
{[\%]}\end{array}$ & $\begin{array}{c}\text { SEC } \\
{[\mu \mathrm{S} / \mathrm{cm} / \mathrm{g} / \mathrm{mL}]}\end{array}$ & $\begin{array}{c}\text { TZ } \\
{\left[\begin{array}{c}\text { assessment } \\
\text { category] }\end{array}\right.}\end{array}$ & $\begin{array}{c}\text { HP } \\
{[\%]}\end{array}$ \\
\hline DJ & Deli Jovan & 30.13 & 6.14 & 0.55 & 4.41 & 20.00 \\
\hline JK & Južni Kučaj & 29.98 & 5.91 & 1.25 & 3.78 & 30.00 \\
\hline KR & Kamenička reka & 30.98 & 6.92 & 1.02 & 3.43 & 10.00 \\
\hline BK & Bukovik & 27.71 & 6.01 & 0.43 & 4.75 & 26.67 \\
\hline CV & Venac-Blagaja & 30.40 & 5.37 & 0.95 & 4.32 & 23.33 \\
\hline SR & Srndaljska reka & 29.14 & 8.94 & 0.62 & 2.80 & 6.67 \\
\hline MC & Miroč & 29.98 & 5.87 & 0.39 & 3.87 & 36.67 \\
\hline VU & Vučje & 24.45 & 7.00 & 1.58 & 2.09 & 13.33 \\
\hline MD & Medveđa & 24.44 & 7.34 & 0.36 & 3.41 & 20.00 \\
\hline KU & Kukavica & 25.66 & 6.68 & 0.82 & 3.50 & 10.00 \\
\hline DU & Dubašnica & 30.99 & 5.73 & 0.67 & 4.40 & 20.00 \\
\hline MJ & Mali Jastrebac & 29.56 & 6.03 & 0.30 & 3.41 & 20.00 \\
\hline
\end{tabular}

WG - weight of 100 seed; HU - humidity; SEC - specific electrical conductivity; TZ - tetrazolium test; HP hydrogen peroxide treatment.

The occurrence of the negative correlation coefficient was confirmed in the previous studies (Ivetić and Milovanović, 2005). This phenomenon occurs because water itself is not a good conductor of electricity, however, when dissolving ions in the water there is an increase in the electrical conductivity and it increases as the concentration of ions in the solution increases. The substances released from the seeds in the water behave as electrolytes, and having in mind that the vital seeds easily restore membranes and thus more effectively release organic matter, the electrical conductivity of water in which were vital seeds will be less than the one in which were less vital seeds. The electrical conductivity test is very fast, easy to use and nondestructive, and thus it certainly has an advantage over the classical methods for determining seed quality. 

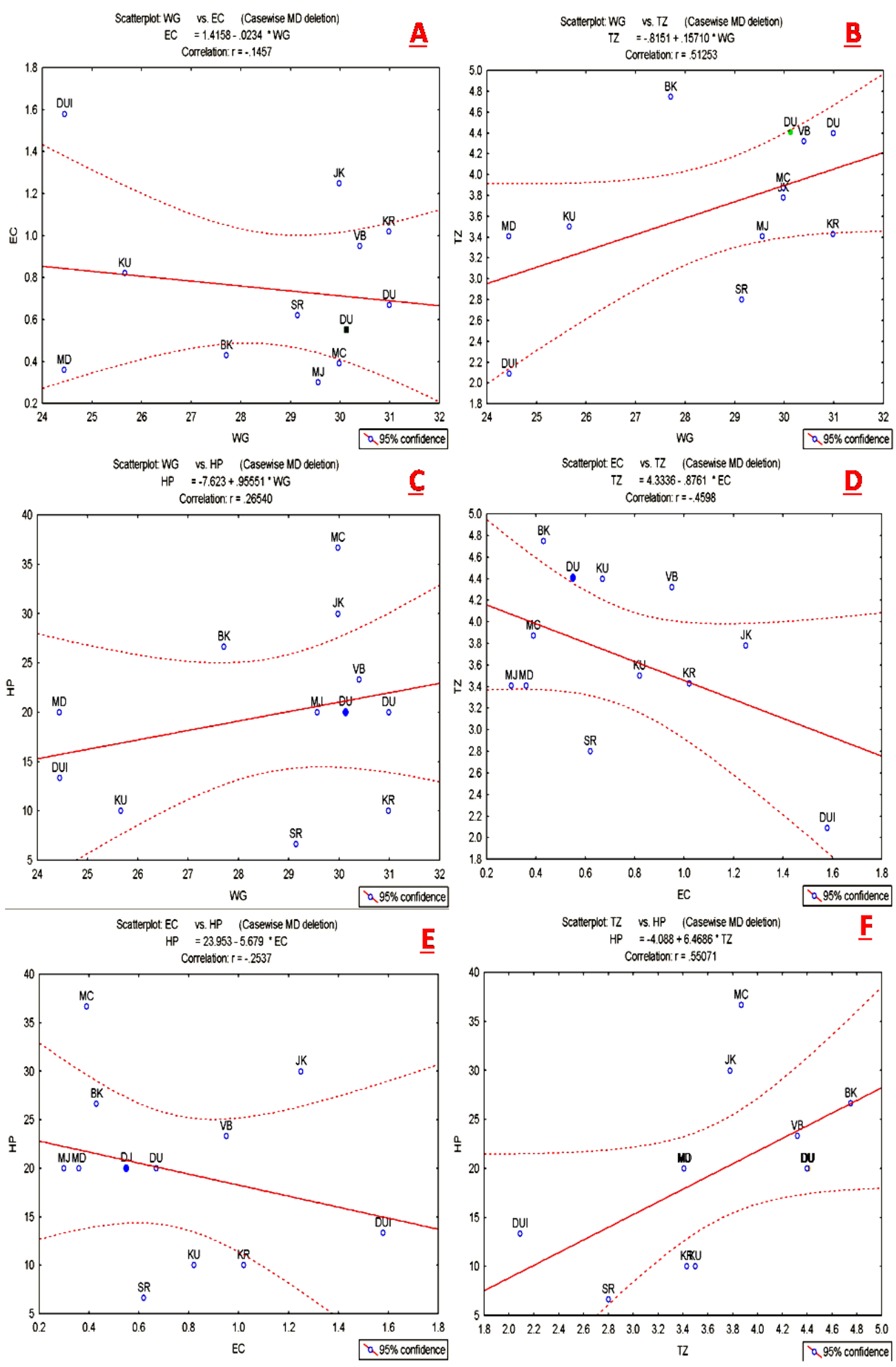

Graph 1. Correlation between: $W G$ and $E C(\underline{A}) ; W G$ and $T Z(\underline{B}) ; W G$ and $H P$ $(\underline{C}) ; E C$ and $T Z(\underline{D}) ; E C$ and $H P(\underline{E}) ; T Z$ and $H P(\underline{F})$. 
Although the tetrazolium test is based on the subjective seed assessment that indicates the possibility of getting unreliable results, the assessment itself largely depends on the skills of technicians who perform it (Ivetić, 2013); when the test is performed appropriately, the percentage of viable seeds is very close to the percentage of seed germinated under most favorable conditions (Verma and Majee, 2013). The hydrogen peroxide treatment can give results that are slightly higher than the results obtained by the germination test, due to the increased oxygen concentration in the solution which accelerates the breathing process, as well as the fungicidal effect of the hydrogen peroxide (Ivetić 2002, 2013).

\section{CONCLUSION}

The electrical conductivity test could be commercially applied in the seed quality assessment, as a quick, simple, materially undesirable and nondestructive, if the relationships between the studied tests and the classical germination test would be determined on a sample which would cover a large number of individuals or populations that are genetically and spatially distant. The standardization of the electrical conductivity test using the tetrazolium test and hydrogen peroxide treatment could contribute to a more quality and more comprehensive determination of the seed quality for commercial purposes.

\section{Acknowledgments}

This paper was realized as a part of the project "Forest plantations in the function of increasing the forestation of Serbia" (TR31041) financed by the Ministry of Education and Science of the Republic of Serbia within the framework of integrated and interdisciplinary research for the period 2011-2018.

\section{REFERENCES}

Comps B., Mátyás C., Letouzey J., Geburek T. (1998): Genetic variation in beech populations (Fagus sylvatica L.) along the Alpine Chain and in the Hungarian Basin. Forest Genetics. 5: 1-9.

Copeland L. O. \& McDonald, M. B. 2001. Principles of seed science and technology Kluwer Academic Publishers, USA

Draper S.R., Bass L.N., Bould A., Gouling P., Hutin M.C., Rennie W.J., Steiner A.M., Tonkin J.H. (1985): Seed science and technology 13 (2). International Seed Testing Association. Zurich, Switzerland.

Edwards D.G.W., Wang B.S.P. (1995): A training guide for laboratory analysis of forcst tree seeds. Infonnation Report BC-X-356. Pacific Forestry Centre, Canadian Forest Service, Nalural Resources Canada. Victoria. British Columbia.

Gosling P.G. (1991): Beechnut storage: a review and practical interpretation of the scientific literature. Forestry 64: 51-59.

Ivetić V. (2002): Possibility of application of hydrogen peroxide methods for determining the vitality of seeds of forest tree species. Forestry 4-6: 1-7. (Mogućnost primene metoda vodonik-peroksida za određivanje vitalnosti semena šumskih vrsta dvreća. Šumarstvo 4-6: $1-7$. 
Ivetić V. (2013): Practicum for seed and nursery production and afforestation. In: ŠijačićNikolić M., Mataruga M., Orlović S. (ed.). University of Belgrade - Faculty of Forestry. Seed quality - parameters and methods of their determination: 37-63. (Praktikum semenarstva, rasadničarstva i pošumljavanja. In: Šijačić-Nikolić M., Mataruga M., Orlović S. (ed.). Univerzitet u Beogradu, Šumarski fakulteta, Beograd. Kvalitet semena - parametri i metodi njihovog utvrđivanja: 37-63.)

Ivetić V., Milovanović J. (2005): The electrical conductivity test for studying spruce seed. Bulletin of the Faculty of Forestry, Belgrade, 91: 127-133. (Test elektične provodljivosti za ispitivanje semena omorike. Glasnik Šumarskog fakulteta, Beograd, 91: 127-133.)

Milošević M., Zlokolica M., Hrustić M., Gvozdenović Đ., Jocković Đ, (1996): Seed dormancy. Selection and seed production 111 (3-4): 97-104. (Mirovanje semena. Selekcija i semenarstvo 111 (3-4): 97-104.)

Muller C. (1993): Combination of dormancy-breaking and storage for tree seeds: new strategies for hardwood species. In: Edwards D.G.W. (ed.) Dormancy and barriers to germination. Proceedings of an international symposium of IUFRO Project Group P2.04-00 (Seed problems) Victoria, British Columbia, Canada, 23-26 April, 1991. 79-85

Muller, C. \& Bonnet-Masimbert, M. 1982. Long term storage of beechnuts: results of large scale trials. In: Wang, B.S.P., Pitel, J.A., (eds.) Proceedings international symposium on forest seed storage; 23-27 Sep. 1980, Canadian Forestry Service Publication, 178-183.

Poter R.H., Durrell M., Romm H.J. (1947): The use of 2,3,5-tiriphenyl-tetrazoliumchloride as a measure of seed germinability. Plant Physiol 22 (2): 149-159.

Pukacka S. (1991): Changes in membrane lipid components and antioxidant levels during natural aging of seeds of Acer platanoides. Physiol Plant 82: 306-10.

Pukacka S., Ratajzcak E. (2004): Production and scavenging of reactive oxygen species in Fagus sylvatica seeds during storage at varied temperature and humidity. Plant Physiol 162 (8): 873-885.

Senaratna T., Gusse J.F., Mc Kersie B.D. (1988): Age-induced changes in cellular membranes of imbibed soybean axes. Physiol Plant 73: 85-91.

Soltani A., 2003: Improvement of Seed Germination of Fagus orientalis Lipsky, Doctoral thesis, Swedish University of Agricultural Sciences, Umeå

Suszka, B. \& Zieta, L. 1977. A new presowing treatment for cold stored beech (Fagus sylvatica L.) seed chilled without medium at a controlled hydration level and pregerminated in cold moist conditions. Arboretum Kornickie, 22: 237-255.

Suszka, B. 1974. Storage of beech (Fagus sylvatica L.) seeds for up to 5 winters. Arboretum kornickie 19: 105-128.

Verma, P. and Majee, M. (2013). Seed Germination and Viability Test in Tetrazolium (TZ) Assay. Bio-protocol3(17): e884. DOI: 10.21769/BioProtoc.884.

Vertucci C.W., Ross E.E. (1990): Theoretical basis of protocols for seed storage. Plant Physiol 94: 1019-23.

Walters C. (1998): Understanding the mechanisms and kinetics of seed aging. Seed Sci Res 8: $223-44$. 


\title{
DIFFERENT METHODS FOR BEECH SEED QUALITY TESTING
}

\author{
Ivona KERKEZ, Slavko PAVLOVIĆ, Aleksandar LUČIĆ, Jovana DEVETAKOVIĆ, \\ Mirjana ŠIJAČIĆ-NIKOLIĆ, Vladan POPOVIĆ
}

\section{Summary}

The seed quality is very important in the nursery production from the economic point of view and optimizing storage conditions is one of the major tasks for producers. The seed quality is mostly assessed by the seed germination rate but this method requires a long period of time for carrying out, namely, in extreme case up to 24 weeks (Edwards and Wang, 1995). Also some viable seeds won't germinate due to dormancy which can be removed. Three different methods for seed quality testing were presented in this paper. The aim of this study is to determine the correlation between the electrical conductivity test, tetrazolium test and hydrogen peroxide treatment.

The seed was collected in 12 different seed stands in Serbia that are commonly used for nursery production. The absolute weight and the moisture content of the sampled seed were measured for each population according to SRPS and ISTA standards. The tested seed sample was randomly taken from the total amount of the collected seed.

The analysis of the obtained results included the calculation of the Pearson correlation coefficient in the statistical software package "Statistica7". The correlation was determined between the recorded results of the seed weight and the electrical conductivity $(\mathrm{r}=-0.15)$; the seed weight and the tetrazolium test $(\mathrm{r}=0.51)$; the seed weight and the hydrogen peroxide treatment $(\mathrm{r}=0.27)$; the electrical conductivity and the tetrazolium test $(\mathrm{r}=-0.46)$; the electrical conductivity and the hydrogen peroxide treatment $(\mathrm{r}=-0.26)$; the tetrazolium test and the hydrogen peroxide treatment $(\mathrm{r}=0.55)$.

The electrical conductivity test could be applied in the seed quality assessment, as a quick, simple, materially undesirable and nondestructive, if the relationships between the studied tests and the classical germination test would be determined on a sample which would cover a large number of individuals or populations that are genetically and spatially distant. The standardization of the electrical conductivity test using the tetrazolium test and hydrogen peroxide treatment could contribute to a more quality and more comprehensive determination of the seed quality for commercial purposes.

\section{RAZLIČITE METODE ZA ISPITIVANJE KVALITETA SEMENA BUKVE}

\author{
Ivona KERKEZ, Slavko PAVLOVIĆ, Aleksandar LUČIĆ, Jovana DEVETAKOVIĆ, \\ Mirjana ŠIJAČIĆ-NIKOLIĆ, Vladan POPOVIĆ
}

\section{Rezime}

U rasadničkoj proizvodnji kvalitet semena je veoma važan sa ekonomskog aspekta i optimizovanje uslova skladištenja semena je jedan od najvažnijih zadataka proivođača. Kvalitet semena se najčešće procenjuje stepenom klijavosti, međutim ovaj metod dugo traje, u ekstremnim slučajevima i do 24 nedelje (Edwards and Wang, 1995). Takođe neka od vitalnih semena neće klijati zbog prisustva dormantnosti koja se može ukloniti. U ovom radu prikazane su tri različite metode za testiranje kvaliteta semena. Cilj istraživanja je utvrđivanje korelacijskih odnosa između testa električne provodljivosti, tetrazolijum testa i tretmana semena vodonik peroksidom.

Seme je sakupjeno iz 12 razlličitih semenskih sastojina na području Srbije, koje se uobičajeno korsite za sakupljanje semna za rasadničku proizvodnju. Za svaku od populacija 
na uzorkovanom semenu izmereni su apsolutna masa semena i vlažnost semena po SRPS i ISTA standardima. Iz ukupne količine sakupljenog semena uzorak za testiranje semena električnom provodljivošću, tetrazolijumom i vodonik peroksidom je nasumično izabran.

Analiza dobijenih rezultata obuhvatila je izračunavanje Pirsonovog koeficijenta korelacije u statističkom program "Statistica 7". Utvrđena je korelacija između zabeleženih rezultata mase semena i električne provodljivosti $(\mathrm{r}=-0,15)$; mase semena i tetrazolium testa $(\mathrm{r}=0,51)$; mase semena i tretmana vodonik peroksidom $(\mathrm{r}=0,27)$; električne provodljivosti i tetrazolijum testa $(\mathrm{r}=-0,46)$; električne provodljivosti i vodonik peroksid tretmana $(\mathrm{r}=-0,26)$; tetrazolijum testa i vodonik peroksid tretmana $(\mathrm{r}=0,55)$.

Kada bi se jasno utvrdili odnosi između ispitivanih testova i klasičnog naklijavanja semena na uzorku koji bi zastupio veliki broj individua odnosno populacija koje su genetički i prostorno udaljene, test električne provodljivosti bi se mogao primenjivati prilikom procene kvaliteta semena bukve, kao brz, jednostavan, materijalno nezahtevan test koji ne oštećuje samo seme. Standardizacija testa električne provodljivosti uz primenu tetrazolijum testa i vodonik peroksid tretmana bi doprinela kvalitetnijem i svobuhvatnijem utvrđivanju kvaliteta semena bukve u komercijalne svrhe. 